\title{
Aktivitas Antijamur Ekstrak Etanol Daun Cengkodok (Melastoma malabathricum) Terhadap Pertumbuhan Malassezia furfur
}

\author{
Willy Sanjaya $^{1}$, Ambar Rialita ${ }^{2}$, Mahyarudin Mahyarudin ${ }^{3 *}$ \\ ${ }^{1}$ Prodi Kedokteran, Fakultas Kedokteran, Universitas Tanjungpura, Indonesia \\ ${ }^{2}$ Departemen Dermatovenerologi, Fakultas Kedokteran, Universitas Tanjungpura, Indonesia \\ ${ }^{3}$ Departemen Mikrobiologi, Fakultas Kedokteran, Universitas Tanjungpura, Indonesia
}

\begin{tabular}{|c|c|}
\hline Article info & Abstract \\
\hline History & Pityriasis versicolor $(P V)$ is an infection on epidermal layer of skin and the \\
\hline Submission: $22-02-2020$ & common caused by a type of yeast that live on the skin named Malassezia \\
\hline Review: 04-09-2020 & furfur. The increasing of fungal resistant against antifungal and high \\
\hline Accepted: $19-01-2021$ & reccurence rate after cured in 2 years about $80 \%$, requires alternative \\
\hline $\begin{array}{l}\text { "Email: } \\
\text { mahyarudin@medical.untan.ac.id }\end{array}$ & $\begin{array}{l}\text { treatment that come from plants. Cengkodok leaves (Melastoma } \\
\text { malabathricum) is used conventionally as an alternative medicine. }\end{array}$ \\
\hline & Cengkodok leaf produces secondary metabolites which have antifungal \\
\hline DOI: $10.33096 /$ jffi.v8i1.614 & $\begin{array}{l}\text { activity. The aim of this study was to investigate the antifungal activity of } \\
\text { ethanolic extract Melastoma malabathricum leaves (EEMML). }\end{array}$ \\
\hline Keywords: & Phytochemical screening of EEMML were performed using Thin Layer \\
\hline Antifungal; Melastoma & Chromatography (TLC). Melastoma malabathricum leaves were extracted \\
\hline $\begin{array}{l}\text { malabathricum; Malassezia } \\
\text { furfur }\end{array}$ & with maceration method using $96 \%$ ethanol. The testing of antifungal \\
\hline & $\begin{array}{l}\text { activity was determined using disc-diffusion method with the concentration } \\
\text { of } 5 \cdot 20 \cdot 50 \cdot 100 \cdot 250 \cdot 500 \mathrm{mmm} \text { Ketoconazole } 10 \text { ug/disc and Itraconazole }\end{array}$ \\
\hline & 8ug/disc was used as positive control while negative control used $10 \%$ \\
\hline & dimethyl sulfoxide (DMSO). EEMML didn't showed zone of inhibition \\
\hline & $\begin{array}{l}\text { against Malassezia furfur although } 100 \% \text { concentration extract used. } \\
\text { EEMML have no antifungal activity against Malassezia furfur. }\end{array}$ \\
\hline
\end{tabular}

\section{Pendahuluan}

Pityriasis versicolor (PV) adalah infeksi superfisial pada kulit yang disebabkan oleh jamur dengan spesies Malassezia. Kasus PV paling sering disebabkan oleh spesies Malassezia furfur (M. furfur) sebanyak 70\% kasus (Crespo EV, Florencio, 2006). Penyakit PV sulit disembuhkan, karena kekambuhan setelah perawatan setinggi $80 \%$ dalam waktu 2 tahun (Gupta and Foley, 2015). Antijamur topikal merupakan lini pertama pengobatan untuk kasus PV. Sampai saat ini belum ada pengobatan yang memberikan hasil memuaskan dalam mengontrol tanda dan gejala PV terutama kekambuhannya, dikarenakan strain $M$. furfur ditemukan telah resisten dengan antijamur seperti golongan azol (Mahmoud Y et al, 2015). Tanaman cengkodok (Melastoma malabathricum) telah digunakan secara tradisional untuk mengobati luka iris, diare, disentri, wasir, sakit gigi, dan sakit perut. Secara ilmiah, menunjukkan aktivitas sebagai antiulserasi, antinyeri, antiinflamasi, antioksidan, aktivitas sitotoksik, dan antijamur. Hasil penelitian Joffry pada tahun 2012, ditemukan bahwa tanaman cengkodok memiliki kandungan flavonoid, triterpenoid, tanin, saponin, alkaloid, steroid, glikosida, dan fenol (Joffry et al., 2012). Daun cengkodok ini diharapkan memperbaiki tampakan kulit pasien PV dan menjadi alternatif antijamur dengan adanya kemampuan meregenerasi kulit, efek antiinflamasi, dan kandungan metabolit sekunder dari daunnya. Pengujian aktivitas antijamur dari ekstrak daun cengkodok belum banyak dilakukan. Pengujian pada jamur Fusarium oxysporum yang merupakan penyebab onikomikosis, menunjukkan aktivitas antijamur pada konsentrasi $100 \%$ sebanyak 20 ul. Penelitian tersebut menunjukkan bahwa terdapat potensi antijamur yang belum banyak diketahui selama ini (Grosvenor, Suprinono and Gray, 1995). Sehingga peneliti tertarik meneliti tanaman cengkodok ini, untuk mengetahui kemampuannya sebagai antijamur terhadap $M$. furfur yang kemudian diharapkan menjadi alternatif antijamur terhadap kasus PV saat ini.

\section{Metode Penelitian}

\section{II.1 Pengambilan dan Penyiapan Sampel}

Sampel berasal dari daun cengkodok (Melastoma malabathricum) segar yang diperoleh dari Jalan Ayani II (Pontianak). Pengambilan sampel tanaman dilakukan pada pagi hari. Tanaman daun cengkodok (Melastoma malabathricum) yang telah dideterminasi di Laboratorium Biologi Fakultas Matematika dan Ilmu Pengetahuan Alam Universitas Tanjungpura, kemudian disortasi dari 
bahan-bahan pengotor. Kemudian daun cengkodok (Melastoma malabathricum) dicuci dengan air mengalir sebanyak 3 kali hingga bersih dan dikeringkan hingga kering dengan cara dianginanginkan (selama \pm 2 minggu) (Prasetyo MS and Entang, 2013; Wahyuni, Guswandi and Rivai, 2014). Daun cengkodok (Melastoma malabathricum) yang telah kering, dihaluskan dengan menggunakan blender (Philips HR2116/00) hingga menjadi serbuk dengan ukuran derajat kehalusan serbuk simplisia yang sesuai. Serbuk simplisia yang ada disimpan dalam wadah kedap kering tertutup rapat dalam ruangan terlindung dari cahaya matahari dengan suhu kamar $\left(15-30^{\circ} \mathrm{C}\right)$ (Departemen Kesehatan Republik Indonesia, 2008).

\section{II.2 Ektraksi Sampel}

Serbuk simplisia daun cengkodok (Melastoma malabathricum) sebanyak $400 \mathrm{mg}$ dimaserasi dengan menggunakan etanol 96\% selama 72 jam dan pada tiap 12 jam sekali-kali dilakukan pengadukan. Hasil maserasi yang sudah direndam 24 jam disaring dengan dan selanjutnya residu kembali dimaserasi kembali selama 24 jam. Filtrat daun cengkodok (Melastoma malabathricum) yang diperoleh, disatukan, dan dipekatkan dengan menggunakan rotary evaporator (Rotavapor® II BUCHI) pada suhu $58^{\circ} \mathrm{C}$ hingga diperoleh ekstrak kental. Ekstrak yang didapat disimpan di dalam wadah kaca yang dilapisi aluminium (Yanti, Mudahar and Irawan, 2008; Wahyuni, Guswandi and Rivai, 2014; Andriyawan, 2015).

\section{II.3 Analisis Fitokimia}

Analisis fitokimia dalam penelitian ini menguji kandungan senyawa metabolit terpenoid, steroid, flavonoid, steroid, dan tanin dilakukan secara kualitatif di Laboratorium Kimia Fakultas Matematika dan Ilmu Pengetahuan Alam Universitas Tanjungpura menggunakan metode Kromatografi Lapis Tipis (KLT) yang disemprot dengan reagen penampak kemudian diinterpretasi secara kuantitatif menggunakan Pemindai KLT (CAMAG TLC Scanner) di Laboratorium Fitokimia Fakultas Farmasi Universitas Gadjahmada. Larutan ekstrak dilarutkan menggunakan eluen terbaik menyesuaikan hasil trial and error berupa diklorometan berbanding asam asetat sebesar 7:3. Larutan ekstrak ditotolkan pada adsorben/ penjerap/ fase diam berupa pelat silika gel 60 F254 (Merck) kemudian dilihat di bawah sinar lampu UV $254 \mathrm{~nm}$ dan $366 \mathrm{~nm}$ untuk melihat spot terbaik dari masingmasing penotolan larutan ekstrak (Hayati et al., 2013; Auzia, Lukmayani and Dasuki, 2017; Sulistyawati, Natalia and Mahyarudin, 2018).

\section{II.4 Penyiapan Jamur Uji}

Isolat jamur $M$. furfur berasal dari Laboratorium Parasitologi Fakultas Kedokteran Universitas Indonesia diambil satu ose lalu dikultur pada media SDA + minyak zaitun $10 \mathrm{ml} / \mathrm{L}$.
Kemudian media SDA yang telah diinokulasi biakan jamur, diinkubasi pada suhu $28^{\circ} \mathrm{C}$ selama $18-24$ jam hingga didapatkan koloni jamur M. furfur (Marselia, Wibowo and Arreneuz, 2015).

Konfirmasi dilakukan secara mikroskopik, satu sengkelit jamur uji dari koloni biakan murni difiksasi pada kaca objek lalu ditetesi Lactophenol Cotton Blue (LPCB) dan kemudian diperiksa di bawah mikroskop dengan perbesaran 400x dan 1000x. Hasil positif ditunjukkan dengan gambaran mikroskopik pseudohifa dan spora seperti "spaghetti and meatballs". Karakterisasi jamur uji secara makroskopik dilakukan dengan mengamati koloni jamur yang terbentuk pada media peremajaan jamur (Prayitno H, 2015).

Koloni jamur M. furfur diambil satu ose kemudian dimasukkan ke dalam $\mathrm{NaCl}$ 0,9 \% dan dihomogenkan dengan vortex (Thermolyne Model M37610-33) untuk disamakan kekeruhan dengan standar Mc Farland 0.5 menggunakan spektrofotometer (UV-2450) dengan hasil absorbansi 0.082 - 0.12 pada panjang gelombang $625 \mathrm{~nm}$ sehingga diperoleh suspensi inokulum yang sesuai standar, yaitu 1-5 x $106 \mathrm{cfu} / \mathrm{ml}$ (Sutton, 2011; Marselia, Wibowo and Arreneuz, 2015; Balouiri, Sadiki and Ibnsouda, 2016).

\section{II.5 Uji Aktivitas Ekstrak Daun Cengkodok terhadap $M$. furfur \\ Pengujian daya hambat ekstrak etanol daun} cengkodok terhadap pertumbuhan jamur $M$. furfur dilakukan dengan metode difusi cakram berdiameter $5 \mathrm{~mm}$. Sebanyak 200 ul suspensi jamur M. furfur dimasukkan ke dalam cawan petri steril dengan cara diapuskan dengan lidi kapas steril pada 15-20 ml media MHA yang telah memadat. Kemudian diletakkan cakram dengan konsentrasi 5;20;50;100;250;500 ppm sebanyak 15 ul, kontrol positif pertama ketokonazol 10ug/disk, kontrol positif kedua itrakonazol 8ug/disk, dan kontrol negatif DMSO 10\% (Cantón and Pemán, 2009; Alastruey et al., 2015; Sarbadhikary et al., 2015; Balouiri, Sadiki and Ibnsouda, 2016; Hasanah, 2017; Peano et al., 2017).

Media yang telah berisi jamur uji kemudian ditutup rapat dan diinkubasikan pada suhu $35^{\circ} \mathrm{C}$ selama 48 jam. Biakan jamur dalam media MHA tersebut diamati zona hambat yang terbentuk kemudian diameter zona hambat diukur menggunakan jangka sorong untuk mengetahui aktivitas antijamur ekstrak etanol daun cengkodok (Melastoma malabathricum). Diameter zona hambat pada waktu 48 jam dikategorikan tingkat responnya berdasarkan Tabel 1 (Shukla and Bhalodia, 2011; Yurayart et al., 2013; Jannata, Gunadi and Ermawati, 2014). 
Tabel 1. Klasifikasi Respon Hambatan Pertumbuhan Jamur (Marotta et al., 2016)

\begin{tabular}{ll}
\hline Diameter Zona Hambat $(\mathbf{m m})$ & Interpretasi \\
\hline$\leq 12$ & Lemah \\
$13-19$ & Sedang \\
$\geq 20$ & Kuat \\
\hline
\end{tabular}

\section{Hasil Dan Pembahasan}

III.1 Analisis Fitokimia

Hasil analisis fitokimia pada penelitian menunjukkan ekstrak etanol daun cengkodok mengandung senyawa metabolit sekunder berupa terpenoid, steroid, flavonoid, steroid, dan tanin. Berdasarkan hasil kuantitatif kandungan metabolit sekunder, didapatkan bahwa golongan senyawa tannin merupakan senyawa paling dominan, sehingga diprediksi aktivitas biologik ekstrak etanol daun cengkodok lebih dominan karena pengaruh golongan senyawa tannin. Hasil kromatografi dalam bentuk pendar noda dapat dilihat pada Gambar 1 dan
Hasil analisis kromatografi dalam bentuk persentase dapat dilihat pada Tabel 2.

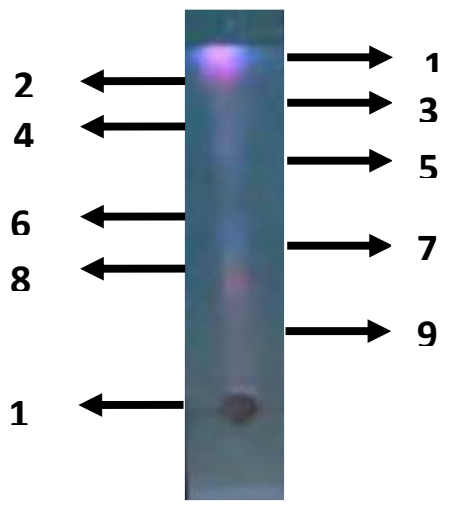

Gambar 1. Pendar noda metabolit sekunder ekstrak daun cengkodok pada KLT di bawah sinar UV $366 \mathrm{~nm}$.

Tabel 2. Persentase noda klt ekstrak etanol cengkodok pada pemindai klt

\begin{tabular}{cccc}
\hline No. & Noda ke- & Persentase $(\%)$ & Golongan \\
\hline 1. & 1 & 1,47 & Terpenoid \\
2. & 2 & 1,79 & Terpenoid \\
3. & 3 & 1,01 & Terpenoid \\
4. & 4 & 3,98 & Terpenoid \\
5. & 5 & 4,98 & Steroid \\
6. & 6 & 4,68 & Flavonoid \\
7. & 7 & 5,67 & Steroid gula \\
8. & 8 & 10,33 & Terpenoid gula \\
9. & 9 & 23,21 & Flavonoid gula \\
10. & 10 & 42,88 & Tanin \\
\hline
\end{tabular}

Berdasarkan hasil skrining fitokimia, didapatkan bahwa tanin merupakan senyawa paling dominan yang terdapat didalam ekstrak yaitu sebesar $42.88 \%$. Tanin memiliki kemampuan untuk mengganggu membran sitoplasma, mengganggu PMF (Proton Motive Force), transpor aktif, dan aliran elektron untuk mengganggu pembuatan ATP pada jamur. Tanin juga mengkoagulasi substansi sel (Ali et al., 2018).

Namun tanin dibagi menjadi dua kelompok yaitu tanin "hydrolysable" (HT) yang berarti tanin yang dapat dihidrolisis dan tanin "condensaded" (CT) yang berarti tanin yang terkondensasi (Singh, Jha and Kumar, 2014). HT dan CT merupakan polifenol dengan berat molekul sedang hingga berat yang menempel dan mempresipitasi protein terlarut. HT memiliki berat molekul yang lebih ringan dibanding CT. Kemampuan biologik/ aktivitas antijamurnya bergantung dari kemampuan untuk menangkal radikal bebas. Efisiensi kerjanya bergantung dari berat molekul, jumlah cincin aromatisnya, dan lebih dominan dipengaruhi oleh subtitusi gugus hidroksilnya dibanding dengan gugus fungsional spesifiknya (Singh, Jha and Kumar, 2014; Naumann et al., 2017).

CT merupakan tanin dengan berat molekul besar dan memiliki aktivitas biologik lebih baik dibanding HT, sehingga dapat digunakan sebagai antimikrob. Hal ini dikarenakan CT memiliki kemampuan untuk berikatan pada polimer dinding sel patogen dan membentuk kompleks yang akan menghambat kerja enzim proteolitik dari patogen sehingga melemahkan sistem imun patogen. Perubahan morfologi diakibatkan oleh intoksikasi dinding sel target oleh tanin. Selain itu, CT juga mampu melakukan penetrai menembus dinding sel dalam konsentrasi yang cukup yang mengakibatkan inhibisi sintesis dinding sel (Singh, Jha and Kumar, 2014; Ali et al., 2018).

HT merupakan tanin dengan komponen fenol sederhana yang memiliki inti tengah berupa glukosa. HT juga bisa merupana fenol yang memiliki inti tengah berupa poliol yang teresterifikasi dengan asam galik (gallotanin) maupun asam heksahidroksidifenat (elagitanin) (Singh, Jha and Kumar, 2014; Altemimi et al., 
2017). Hingga saat ini tanin yang berhasil ditemukan pada tanaman cengkodok (Melastoma malabathricum) adalah tujuh tanin monomer $(1,4,6-$ tri- $O$-galloyl- $\beta$-D-glucoside, $\quad 1,2,4,6$-tetra- $O$ galloyl- $\beta$-D-glucoside, strictinin, casuarictin, pedunculagin, nobotanin $\mathrm{D}$, and pterocarinin $\mathrm{C}$ ) dan empat tanin oligomer (nobotanins $\mathrm{B}, \mathrm{G}$, and $\mathrm{H}$ (dimers) and nobotanin $\mathrm{J}$ (trimer)), dan 3 tanin spesifik bernama malabathrins B, C, and D. Semua ke-14 tanin tersebut merupakan tanin yang dapat dihidrolisis (HT) (Joffry et al., 2012).

\section{III.2 Uji Aktivitas Antijamur}

Uji aktivitas antijamur pada penelitian ini dilakukan di Laboratorium Parasitologi dan Mikroskopik Fakultas Kedokteran. Pengujian dilakukan menggunakan 6 kelompok perlakuan dengan variasi konsentrasi ekstrak etanol daun cengkodok yaitu: $5 ; 20 ; 50 ; 100 ; 250 ; 500$ ppm. Cakram yang direndam sampai terserap pada keenam esktrak etanol daun cengkodok tersebut diujikan pada media MHA yang telah diinokulasi jamur M. furfur sebanyak 200uL. Pengamatan dilakukan setelah inkubasi 3x24 jam pada suhu sesuai. Hasil inkubasi menunjukkan zona hambat sebesar $0 \mathrm{~mm}$ pada setiap konsentrasi dan kontrol positif pertama. Sedangkan pada kontrol positif kedua didapatkan zona hambat sebesar $36.79 \mathrm{~mm}$. Hasil uji antijamur dapat dilihat pada Gambar 2 dan Tabel 3.

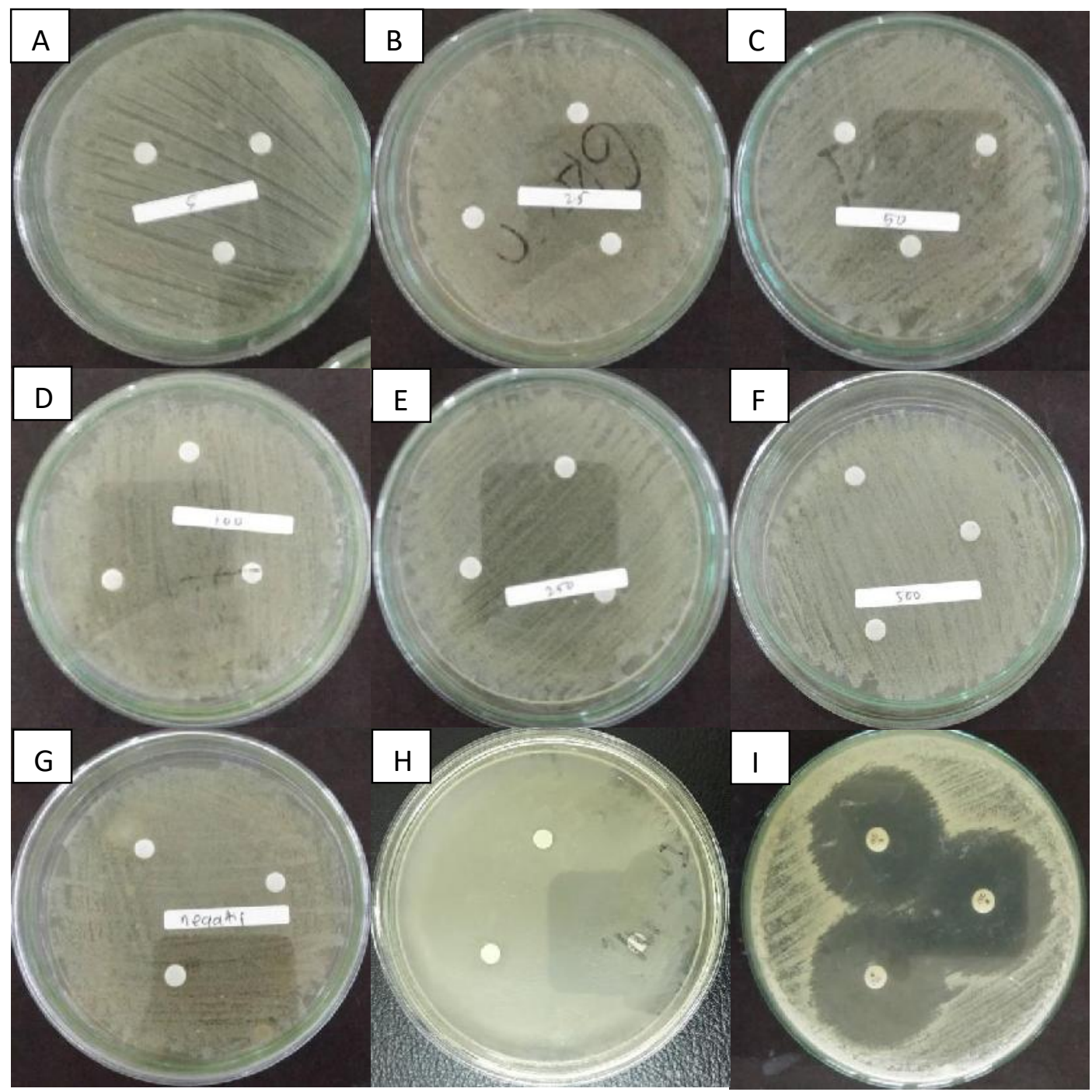

Gambar 2. Hasil uji aktivitas antijamur dengan variasi konsentrasi ekstrak etanol daun cengkodok (A) 5 ug/ml; (B) $20 \mathrm{ug} / \mathrm{ml}$; (C) $50 \mathrm{ug} / \mathrm{ml}$; (D) $100 \mathrm{ug} / \mathrm{ml}$; (E) $250 \mathrm{ug} / \mathrm{ml}$; (F) $500 \mathrm{ug} / \mathrm{ml}$; (G) kontrol negatif; (H) kontrol positif pertama (ketokonazol); dan (I) kontrol positif kedua (itrakonazol) 
Tabel 3. Hasil Uji Aktivitas Antijamur Ekstrak Etanol Daun Cengkodok (Melastoma malabathricum) Terhadap Pertumbuhan $M$. furfur.

\begin{tabular}{|c|c|c|c|c|c|c|}
\hline \multirow{3}{*}{ No } & \multirow{3}{*}{ Konsentrasi } & \multirow{2}{*}{\multicolumn{3}{|c|}{$\frac{\text { Diameter Zona Hambat (mm) }}{\text { Pengulangan ke- }}$}} & \multirow{3}{*}{$\begin{array}{c}\text { Rata-rata } \\
(\mathbf{m m})\end{array}$} & \multirow{3}{*}{ Keterangan } \\
\hline & & & & & & \\
\hline & & $\mathrm{I}$ & II & III & & \\
\hline 1 & 5 ppm & 0 & 0 & 0 & 0 & Tidak ada zona hambat \\
\hline 2 & $20 \mathrm{ppm}$ & 0 & 0 & 0 & 0 & Tidak ada zona hambat \\
\hline 3 & $50 \mathrm{ppm}$ & 0 & 0 & 0 & 0 & Tidak ada zona hambat \\
\hline 4 & $100 \mathrm{ppm}$ & 0 & 0 & 0 & 0 & Tidak ada zona hambat \\
\hline 5 & $250 \mathrm{ppm}$ & 0 & 0 & 0 & 0 & Tidak ada zona hambat \\
\hline 6 & $500 \mathrm{ppm}$ & 0 & 0 & 0 & 0 & Tidak ada zona hambat \\
\hline 7 & Kontrol (-) & 0 & 0 & 0 & 0 & Tidak ada zona hambat \\
\hline 8 & Kontrol (+)1 & 0 & 0 & 0 & 0 & Resisten \\
\hline 8 & Kontrol $(+) 2$ & 36,38 & 35,86 & 38,15 & 36,79 & Sensitif \\
\hline
\end{tabular}

Uji aktivitas antijamur pada penelitian ini menggunakan metode difusi cakram. Terdapat lima kelompok perlakuan dengan variasi konsentrasi ekstrak etanol daun cengkodok $5 ; 20 ; 50 ; 100 ; 250$; dan 500 ppm serta dua kelompok kontrol yaitu kontrol positif menggunakan itrakonazol 8ug/disk dan kontrol negatif DMSO 10\%. Penggunaan ketokonazol dan itrakonazol karena memiliki MIC terendah dibandingkan dengan antijamur lainnya menjadikannya dipilih sebagai antijamur topikal yang luas digunakan, namun dikarenakan penggunaan yang luas dan tidak sesuai dosis meningkatkan risiko resistensinya jamur $M$. furfur (Alastruey et al., 2015). Resistensi terhadap ketokonazol ditemukan pada saat perlakuan diinterpretasikan dari tidak adanya zona hambat yang terbentuk (0mm).

Kontrol positif pertama ketokonazol tidak menunjukkan zona hambat yang berarti $M$. furfur telah resisten terhadap ketokonazol. Mekanisme kerja golongan azol adalah dengan menarget jalur biosintesis ergosterol melalui penghambatan dari enzim utama yaitu enzim $14 \alpha$-sterol demetilase yang berfungsi untuk mengonversi lanosterol menjadi ergosterol (Alastruey et al., 2015). Penghambatan yang terjadi mengarahkan enzim tersebut melakukan sintesis komponen toksik yang tidak dapat mengganti ergosterol sebagai penyusun utama membran sel, akumulasi komponen toksik tersebut membuat membran sel menjadi rentan, mudah lisis, dan mengarah kepada kematian sel jamur. Namun karena penggunaan yang tidak tepat seperti dosis yang kurang dan durasi penggunaan yang kurang tepat, dapat menyebabkan tempat perlekatan/alosterik enzim $\alpha$-sterol demetilase tersebut bermutasi sehingga tidak dikenal oleh golongan azol dan resistensi pun terjadi (Center of Disease Control and Prevention, 2018). Resistensi yang terjadi terhadap ketokonazol (golongan imidazol) tidak menutup kemungkinan akan terjadi resistensi silang terhadap itrakonazol (triazol) (Muller, 2000; Vandeputte, Ferrari and Coste, 2012).
Kontrol positif kedua itrakonazol 8 ug/disk menunjukkan adanya zona hambat dengan diameter rata-rata $36.79 \mathrm{~mm}$ dengan interpretasi sensitif. Berdasarkan penelitian yang dilakukan, ditemukan bahwa $M$. furfur sudah tidak sensitif pada ketokonazol dan masih sensitif pada itrakonazol. Hal ini didukung oleh mekanisme kerja golongan azol yang menghambat kerja enzim $14 \alpha$-sterol demetilase dengan cara mengikatkan nitrogen dari cincin azolnya pada gugus heme enzim $14 \alpha$-sterol demetilase. Ketokonazol merupakan golongan imidazol karena memiliki 2 atom nitrogen dan itrakonazol merupakan golongan triazol karena memiliki 3 atom nitrogen. Ketokonazol memiliki 2 atom nitrogen yang tidak berdekatan pada senyawa kimianya sedangkan triazol memiliki 3 atom nitrogen yang berdekatan. Resistensi akibat mutasi yang terjadi pada enzim menyebabkan penurunan afinitas terhadap golongan azol. Hal ini terjadi pada ketokonazol karena struktur kimia ketokonazol memiliki hanya 2 atom nitrogen dengan jarak berjauhan, berbeda dengan itrakonazol yang memiliki struktur kimia yang lebih aktif dengan 3 atom nitrogen dan berdekatan menyebabkan penurunan afinitas tidak mempengaruhi proses mekanisme kerjanya sehingga masih sensitif (Vandeputte, Ferrari and Coste, 2012; Campestre et al., 2017).

Sedangkan pada kontrol negatif menggunakan DMSO $10 \%$ tidak menunjukkan adanya zona hambat yang terbentuk disekitar kertas cakram. DMSO $10 \%$ adalah zat yang digunakan untuk melarutkan ekstrak saat pembuatan berbagai konsentrasi larutan uji, maka dari itu DMSO $10 \%$ harus bersifat negatif dan tidak memberikan aktivitas antijamur (Rojas et al., 2017).

Hasil pengujian aktivitas antijamur menggunakan ekstrak etanol daun cengkodok (Melastoma malabathricum) menunjukkan tidak adanya zona hambat yang terbentuk $(0 \mathrm{~mm})$ yang berarti ekstrak etanol daun cengkodok tidak efektif dalam menghambat pertumbuhan M. furfur. Ada tiga faktor yang dapat mempengaruhi tidak adanya 
aktivitas antijamur tersebut, yaitu faktor teknis seperti kurangnya konsentrasi ekstrak, kontaminasi koloni pada petri, suspensi jamur yang tidak sesuai standar, suhu yang tidak sesuai standar, lama inkubasi yang tidak sesuai standar. Faktor ekstrak etanol daun cengkodok, dapat berupa pengaruh pelarut, maupun kandungan metabolit sekunder dominan yang mempengaruhi hasil uji. Faktor ketiga adalah faktor biologis seperti kepekaan jamur uji dan properti khusus yang dimiliki patogen (Jenkins and Schuetz, 2012; Altemimi et al., 2017; Li et al., 2017; Bayot and Bragg, 2019).

Uji konfirmasi menggunakan konsentrasi ekstrak yang lebih tinggi yaitu $5000 \mathrm{ppm}, 10 \%$, $20 \%, 30 \%$. 40\%, 50\%, 60\%, 70\%, $80 \%, 90 \%, 100 \%$ telah dilakukan dan tidak ditemukan zona hambat $(0$ $\mathrm{mm}$ ). Kontaminasi pada petri juga tidak ditemukan sehingga tidak mengganggu hasil pengujian. Hal ini berarti faktor teknis pertama dan kedua telah dapat peneliti singkirkan (Vandeputte, Ferrari and Coste, 2012).

Penggunaan suspensi jamur juga telah distandarkan kekeruhannya menggunakan larutan standar Mc. Farland 0.5 kemudian dikonfirmasi menggunakan spektrofotometer dan didapatkan serapan pada 0.103 yang menunjukkan bahwa suspensi jamur uji berkonsentrasi $1-5 \times 10^{6}$ dan berada dalam fase logaritmik (tetap membelah) sehingga cocok digunakan dalam pengujian aktivitas antijamur, jumlah suspensi jamur yang diinokulasikan pada media MHA juga sama yaitu 200ul suhu inkubasi juga berada pada suhu ideal $30 \pm 2^{\circ} \mathrm{C}$ selama 48 jam. Hal ini berarti faktor teknis ketiga, keempat, dan kelima telah dapat peneliti singkirkan (Vandeputte, Ferrari and Coste, 2012; Alastruey et al., 2015).

Uji sensitivitas antijamur telah dilakukan dan menunjukkan bahwa strain $M$. furfur pada penelitian ini sudah resisten terhadap ketokonazol dan masih sensitif terhadap itrakonazol (Vandeputte, Ferrari and Coste, 2012). Tidak adanya zona hambat yang terbentuk diduga karena kandungan metabolit sekunder yang tidak adekuat untuk menembus pertahanan $M$. furfur kemudian dengan adanya properti struktur dinding sel $M$. furfur yang kompleks, kemampuan membedakan self dan nonself dengan adanya Nucleotide oligomerization domain (NOD)-like receptors (NLRs), fasilitas "drug efflux pumps", dan didukung oleh kemampuan membentuk biofilm. Properti tersebut diduga memberikan proteksi kepada jamur $M$. furfur terhadap agen antijamur. Faktor biologis tersebut berada diluar kendali peneliti.

Pengujian aktivitas antijamur terhadap jamur $M$. furfur yang menggunakan pelarut lain juga menunjukkan tidak ada aktivitas meskipun menggunakan berbagai pelarut seperti ekstrak kloroform, heksan, air buah Punica granatum yang menunjukkan tidak ada zona hambat $(0 \mathrm{~mm})$, ekstrak kloroform, metanol, air dari buah Illicium veruk (Hook) yang menunjukkan tidak adanya zona hambat $(0 \mathrm{~mm})$, ekstrak kloroform, air dari daun Nycanthes arbor-tristis (L) yang menunjukkan tidak adanya zona hambat $(0 \mathrm{~mm})$, ekstrak kloroform, heksan, metanol, air dari daun Thespesia populnea (L) dan daun Piper betle (L) juga menunjukkan tidak adanya zona hambat $(0 \mathrm{~mm})$. Hal ini menunjukkan bahwa pelarut tidak memiliki pengaruh signifikan, begitu pula etanol yang digunakan pada penelitian ini (Lalitha et al., 2016).

Berdasarkan hasil KLT didapatkan bahwa pendar noda tanin yang terletak di bawah plat silika (polar) yang menunjukkan kepolaritasannya yang sangat polar, hal ini dikarenakan adanya gugus gula yang ada pada tanin. Sehingga sejalan dengan teori bahwa tanaman cengkodok memiliki tanin yang dapat dihidrolisis (HT). Adapun HT merupakan tanin yang lemah dikarenakan penyusunnya hanya berupa fenol sederhana, memiliki berat molekul ringan dibanding $\mathrm{CT}$, sehingga tanin pada ekstrak cengkodok memiliki aktivitas antijamur yang tidak baik. HT juga mudah dipengaruhi oleh beberapa hal seperti komponen alkalin dan asam mineral yang mampu berikatan dan mengganggu kerja tanin.

Metabolit sekunder utama yang diharapkan adalah flavonoid, karena kemampuannya yang dapat mendenaturasi protein dan bekerja dengan meningkatkan permeabilitas membran sel secara langsung dan berikatan dengan protein melalui ikatan hidrogen yang menyebabkan terganggunya struktur protein yang mengarah pada lisis sel dan kematian sel (Ronaa et al., 2018). Pengujian aktivitas antijamur ekstrak daun Eucalyptus globulus terhadap jamur $M$. furfur menunjukkan zona hambat yang kuat terhadap yaitu sebesar (30 \pm 1.63) mm dengan metabolit sekunder dominan berupa flavonoid sebesar $35.88 \%$ (Vijayakumar et al., 2006; Kaur, Gupta and Gautam, 2019).

Adapun enzim yang mampu merusak tanin seperti Tannin acyl hydrolase (tanase) yang dapat pula dihasilkan oleh jamur filamentosa. Hingga saat ini penelitian mengenai jamur penghasil tanase juga masih dikembangkan. Jamur penghasil tanase yang paling banyak diteliti adalah jamur filamentosa (Aboubakr, 2012; Altemimi et al., 2017). Dalam penelitian Mahada pada tahun 2012 berhasil menemukan jamur filamentosa yang telah berhasil ditemukan memiliki kemampuan memproduksi enzim tanase adalah Aspergillus niger, Aspergilus flavus, Aspergilus sp., Fusarium spp., Penicillium spp., Trichoderma spp., dan ada dua yang belum berhasil diidentifikasi. $M$. furfur merupakan jamur filamentosa pada fase patogeniknya, namun masih membutuhkan penelitian lebih lanjut untuk membuktikan $M$. furfur mampu memproduksi tanase (Gayen and Ghosh, 2013).

Aktivitas antijamur terhadap jamur $M$. furfur juga tidak ditemukan dengan penggunaan ekstrak etanol umbi bawang dayak (Diana, Sari and Aisyah, 2017). Namun perbedaan hasil ditemukan 
pada pengujian pada jamur yang berbeda pada jamur Trichophyton mentagrophytes menunjukkan adanya zona hambat sebesar $9.15 \mathrm{~mm}$, dan pada jamur Trichophyton rubrum menunjukkan zona hambat sebesar $14.03 \mathrm{~mm}$ (Puspadewi, Adirestuti and Menawati, 2013; Christoper, Diana and Sari, 2017). Hal ini didukung dengan hasil penelitian pengujian aktivitas antijamur daun cengkodok (Melastoma malabathricum) terhadap jamur T. mentagrophytes dan Candida albicans yang menunjukkan zona hambat sebesar $30 \mathrm{~mm}$ dan $21 \mathrm{~mm}$ (Gholib, 2009). Hal ini diduga dipengaruhi oleh dinding sel yang dimiliki oleh kedua jamur tersebut yang berbeda. Agen antijamur harus berkontak dengan dinding sel jamur dan berdifusi masuk ke dalam sitoplasma jamur untuk dapat bekerja, namun apabila proses tersebut terganggu maka agen antijamur tidak dapat bekerja dan tidak menunjukkan adanya zona hambat dalam hal ini diinterpretasikan tidak memiliki aktivitas antijamur (Scorzoni et al., 2017).

Genus Malassezia memiliki dinding sel multilamelar yang tebal, secara biokimia relatif inert, dan pada bagian bawah dinding selnya terdapat konfigurasi gerigi yang menginvaginasi ke bagian membran sel. Genus Malassezia adalah satu satunya jamur dengan dinding sel berpola helikoid, sangat kompleks, sehingga memiliki struktur dinamis yang tidak mudah rusak untuk melindungi sel dari perubahan tekanan osmotik dan stres lingkungan (Stalhberger et al., 2014). Lapisan dinding sel multilamerlar seperti kapsul tersebut mengandung lemak dan dibutuhkan pelarut untuk merusaknya (Ashbee, 2007). Kekuatan dinding sel jamur ini penting untuk integritas dan kelangsungan hidup sel jamur terutama karena adanya ikatan silang antara polisakarida dengan berat molekul tinggi. Penelitian mengenai komposisi dinding sel genus Malassezia masih sedikit dilakukan, yang ditemukan dalam dinding sel setelah difraksi menggunakan air adalah $\beta$-(1,3)-glukans, $\beta$-(1,6)glukans, galaktofuran, dan struktur manan (Shibata et al., 2009). Polimer-polimer tersebut saling berhubungan dengan ikatan kovalen (ikatan terkuat) dan membentuk kompleks yang kuat. Struktur $\beta$ $(1,6)$-glukans yang berlimpah merupakan penyusun dominan dinding sel jamur dibanding struktur lainnya dan diperkirakan memiliki molekul sebesar 1500 unit glukosa/ rantai dengan rata-rata $500 \mathrm{kDa}$ untuk kompleks $\beta$ glukans, $80 \mathrm{kDa}$ untuk $\beta$ - $(1,6)$ glukans, dan $10 \mathrm{kDa}$ untuk $\beta$ - $(1,3)$-glukans (Shibata et al., 2009).

Adanya aktivitas antijamur pada ekstrak daun cengkodok pada penggunaan konvensional masyarakat dalam menangani onikomikosis yang disebabkan oleh Fusarium oxysporum juga didasarkan pada ketebalan dinding sel $F$. oxysporum yang tipis jika dibanding dengan dinding sel $M$. furfur. Apabila ditinjau menggunakan mikroskop elektron, ketebalan dinding sel M. furfur sebesar 0.1803 um dan ketebalan dinding sel $F$. oxysporum adalah 0.0404 um sehingga menunjukkan bahwa dinding sel $M$. furfur memiliki ketebalan 4,46 kali dari ketebalan dinding sel $F$. oxysporum (Schoffelmeer et al., 1999; Boekhout et al., 2010). Jamur $M$. furfur juga memiliki ketebalan 4,05 kali dari ketebalan dinding sel Trichophyton rubrum (0.0445 um) (Aala et al., 2014). Tebalnya dinding sel $M$. furfur beserta penyusunnya yang kompleks, diduga sebagai penyebab perbedaan hasil yang ditampakkan pada pengujian aktivitas antijamur ekstrak daun cengkodok terhadap berbagai jamur.

Metabolit sekunder termasuk komponen yang memiliki berat molekul rendah (<900dalton) memungkinkan dirinya untuk dapat masuk menembus dinding sel $M$. furfur, namun $M$. furfur mampu memproteksi dirinya dengan memompa keluar agen antijamur berupa metabolit sekunder tersebut menggunakan fasilitas "drug efflux pumps". Penelitian yang dilakukan Uehling $\mathbf{J}$ pada tahun 2017, menunjukkan bahwa jamur juga memiliki sistem pertahanan yang sama dengan tanaman dan binatang yaitu Nucleotide oligomerization domain (NOD)-like receptors (NLRs) yang mampu membedakan self dan non-self bagi jamur. Ini diduga sebagai penyebab jamur $M$. furfur memompa keluar kandungan metabolit sekunder cengkodok akibat terdiskriminasi oleh NRLs tersebut (Iatta R and Otranto D, 2017; Uehling, Deveau and Paoletti, 2017).

Jamur $M$. furfur dalam kondisi bertahan hidup melawan stres lingkungan juga membentuk biofilm yang berfungsi untuk mekanisme protektif terhadap mikrob lain, mampu menghindar dari sistem imun manusia, menyediakan kondisi aman untuk proliferasi dirinya, dan berperan sebagai barier/pelindung dari agen-agen antijamur seperti metabolit sekunder. Perlindungan yang ada ini memproteksi jamur dari destruksi yang disebabkan oleh metabolit sekunder dengan mencegah difusi metabolit sekunder menuju sitoplasma atau bahkan menghinaktivasi dengan berikatan langsung. Adanya barier ini juga menyediakan kondisi $\mathrm{pH}$ rendah, dan tinggi konsentrasi ion metalik. Hal ini diduga yang menyebabkan kandungan metabolit sekunder tidak mampu masuk berdifusi menuju kedalam sel jamur (Allen, Goyal and Ogrich, 2015).

\section{IV.Kesimpulan}

Kandungan metabolit sekunder yang terdapat pada ekstrak etanol daun cengkodok adalah flavonoid, terpenoid, steroid, dan tanin. Metabolit sekunder dominan adalah tanin. Tidak ada zona hambat yang dihasilkan oleh ekstrak etanol daun cengkodok terhadap jamur $M$. furfur meskipun konsentrasi telah ditingkatkan hingga $100 \%$. Tidak ada konsentrasi efektif dari ekstrak etanol daun cengkodok dalam menghambat pertumbuhan jamur $M$. furfur. Saran bagi peneliti selanjutnya, disarankan melakukan modifikasi dengan penambahan pelarut/solven pada ekstrak untuk 
merusak lapisan dinding sel $M$. furfur yang tebal berlemak dan merusak biofilm yang dibentuk $M$. furfur sebagai proteksi dari agen antijamur, sehingga metabolit sekunder dapat berdifusi lancar ke intrasel, kemudian menggunakan strain $M$. furfur yang masih baru diremajakan dari sumbernya dan tidak resisten terhadap ketokonazol sebagai lini pertamanya. Serta melakukan kombinasi pada ekstrak etanol daun cengkodok dengan bahan alam lainnya yang bekerja sinergis sehingga meningkatkan kemampuan antijamurnya.

\section{Daftar Pustaka}

Aala, F. et al. (2014) 'Inhibitory effect of allicin and garlic extracts on growth of cultured hyphae', Iran J Basic Med Sci, 17(March), pp. $150-154$.

Aboubakr, H. A. (2012) Tannase-producing fungi : isolation, screening, identification and optimizing the enzyme production. 1st edn. USA: LAP lambert academic publishing.

Alastruey et al. (2015) 'Susceptibility test for fungi: clinical and laboratorial correlations in medical mycology', Revista do Instituto de Medicina Tropical de São Paulo, 57(suppl 19), pp. 57-64. doi: 10.1590/s003646652015000700011.

Ali, S. et al. (2018) 'Phytochemical investigation and antimicrobial appraisal of Parrotiopsis jacquemontiana ( decne ) rehder', BMC Complementary and Alternative Medicine, 18(1), p. 43. doi: 10.1186/s12906-0182114-z.

Allen, H., Goyal, K. and Ogrich, L. (2015) 'Biofilm formation by malassezia furfur/ovale as a possible mechanism of pathogenesis in tinea versicolor', Journal of Clinical \& Experimental Dermatology Research, 06(06), pp. 1-4.

Altemimi, A. et al. (2017) 'Phytochemicals: extraction, isolation, and identification of bioactive compounds from plant extracts', Plants (Basel), 6(42), pp. 1-23.

Andriyawan, F. (2015) 'Uji aktivitas antibakteri ekstrak etanol daun cengkodok (melastoma malabathricum 1.) terhadap escherichia coli secara in vitro', Jurnal Pendidikan Dokter Kalbar, 3(1), p. 1. doi: http://dx.doi.org/10.1016/j.rasd.2012.07.00 4.

Ashbee, H. R. (2007) 'Update on the genus malassezia', Medical Mycology, 45(4), pp. 287-303. doi: 10.1080/13693780701191373.

Auzia, N., Lukmayani, Y. and Dasuki, U. (2017) 'Isolasi dan identifikasi senyawa metabolit sekunder ekstrak n-heksan dari umbi lobak (raphanus sativus lamk)', Prosiding Farmasi, 2, pp. 285-293.

Balouiri, M., Sadiki, M. and Ibnsouda, S. K. (2016) 'Methods for in vitro evaluating antimicrobial activity: a review', Journal of Pharmaceutical Analysis. Elsevier, 6(2), pp. 71-79. doi: 10.1016/j.jpha.2015.11.005.

Bayot, M. and Bragg, B. (2019) Antimicrobial susceptibility testing. Florida: Treasure Island (FL): StatPearls Publishing.

Boekhout, T. et al. (2010) Malassezia and the skin: Science and clinical practice. SpringerVerlag Berlin Heidelberg. doi: 10.1007/978-3-642-03616-3.

Campestre, C. et al. (2017) 'Analysis of imidazoles and triazoles in biological samples after microextraction by packed sorbent', Journal of Enzyme Inhibition and Medicinal Chemistry. Informa UK Ltd., 32(1), pp. 1-11. doi: 10.1080/14756366.2017.1354858.

Cantón, E. and Pemán, J. (2009) 'Trends in antifungal susceptibility testing using CLSI reference and commercial methods', Expert Rev Anti Infect Ther, pp. 107-119.

Center of Disease Control and Prevention (2018) Antifungal resistance, National Center for Emerging and Zoonotic Infectious Diseases. $\quad$ doi: https://doi.org/10.25077/jka.v6i3.758.

Christoper, W., Diana, N. and Sari, R. (2017) 'Uji aktivitas antijamur ekstrak etanol umbi bawang dayak ( eleutherine americana ( aubl .) merr . ex k . heyne .) terhadap trichophyton mentagrophytes secara in vitro', Jurnal Kesehatan Andalas, 6(3), pp. 910-921.

Crespo EV, Florencio, V. (2006) 'Malassezia yeasts and pityriasis versicolor.', Current opinion in infectious diseases, 19(2), pp. 139-147.

Departemen Kesehatan Republik Indonesia (2008) Farmakope herbal Indonesia, Departemen Kesehatan. Jakarta.

Diana, N., Sari, R. and Aisyah (2017) 'Uji aktivitas antijamur ekstrak etanol umbi bawang dayak (eleutherine americana (aubl.) merr. ex k. heyne) terhadap malassezia furfur secara in vitro', Jurnal Mahasiswa PSPD FK Universitas Tanjungpura, 5(1), p. 3.

Gayen, S. and Ghosh, U. (2013) 'Purification and characterization of tannin acyl hydrolase produced by mixed solid state fermentation of wheat bran and marigold flower by penicillium notatum ncim 923', Biomed Res Int., 2013(1), p. 1. doi: $10.1155 / 2013 / 596380$.

Gholib, D. (2009) 'Uji daya hambat daun senggani (melastoma malabathricum 1.) terhadap trichophyton mentagrophytees dan candida albicans', Berita Biologi, 9(5), p. 523.

Grosvenor, P. W., Suprinono, A. and Gray, D. O. (1995) 'Medicinal plants from Riau Province, Sumatra, Indonesia-part 2: 
antibacterial and antifungal activity', Journal of Ethnopharmacology, 45(94), pp. 97-111.

Gupta, A. and Foley, K. (2015) 'Antifungal treatment for pityriasis versicolor', Journal of Fungi, 1(1), pp. 13-29.

Hasanah, K. (2017) 'Uji daya antifungi propolis terhadap candida albicans dan pityrosporum ovale', Bioedukasi, 10(2), pp. 44-46.

Hayati, E. et al. (2013) 'Identifikasi senyawa metabolit sekunder ekstrak n-heksana batang kesembukan (paederia foetida linn)', Alchemy, 2(3), pp. 150-153.

Iatta R and Otranto D, C. C. P. M. I. D. (2017) 'The role of drug efflux pumps in malassezia pachydermatis and malassezia furfur defence against azoles', Mycoses, 60(3), pp. 178-82.

Jannata, R. H., Gunadi, A. and Ermawati, T. (2014) 'Daya antibakteri ekstrak kulit apel manalagi (malus sylvestris mill.) terhadap pertumbuhan streptococcus mutans', $e$ Journal Pustaka Kesehatan, 2(1), pp. 2328.

Jenkins, S. G. and Schuetz, A. N. (2012) 'Current concepts in laboratory testing to guide antimicrobial therapy', Mayo Clin Proc. Elsevier Inc., 87(3), pp. 290-308.

Joffry, S. M. et al. (2012) 'Melastoma malabathricum (1.) smith ethnomedicinal uses, chemical constituents, and pharmacological properties: a review', Evidence-based Complementary and Alternative Medicine, 2012(Table 1), pp. 6-20.

Kaur, S., Gupta, S. and Gautam, P. B. (2019) 'Phytochemical analysis of eucalyptus leaves extract', Pharmacognosy and Phytochemistry, 8(January), pp. 2442-6.

Lalitha, S. et al. (2016) 'Insignificant antifungal activity of plant extracts on malassezia furfur', Journal of Pharmaceutical Negative Results, 7(1), p. 16.

Li, J. et al. (2017) 'Antimicrobial activity and resistance: influencing factors', Front Pharmacol, 13(8), p. 364.

Mahmoud Y, Metwally M, Mubarak H, Zewawy, N. (2015) 'Treatment of tinea versicolor caused by malassezia furfur with dill seed extract: an experimental study', International Journal of Pharmacy and Pharmaceutical Sciences, 7(2), pp. 1-7.

Marotta, S. M. et al. (2016) 'Evaluation of the antibacterial activity of bergamot essential oils on different listeria monocytogenes strains', Ital J Food Saf, 5(4), p. 6176.

Marselia, S., Wibowo, M. A. and Arreneuz, S. (2015) 'Aktivitas antibakteri ekstrak daun soma (ploiarium alternifolium melch) terhadap propionibacterium acnes', Jurnal Kimia Khatulistiwa, 4(4), p. 1.

Muller, F. (2000) 'Azole cross-resistance to ketoconazole, fluconazole, itraconazole and voriconazole in clinical candida albicans isolates from hiv-infected children with oropharyngeal candidosis', Journal of Antimicrobial Chemotherapy, 46(2), pp. 338-341. doi: 10.1093/jac/46.2.338.

Naumann, H. D. et al. (2017) 'The role of condensed tannins in ruminant animal production: advances, limitations and future directions', $R$ Bras Zootec, 46(12), pp. 929-949.

Peano, A. et al. (2017) 'Methodological issues in antifungal susceptibility testing of malassezia pachydermatis', $J$ Fungi (Basel)., 5(3), p. 3.

Prasetyo MS and Entang, I. (2013) Pengelolaan budidaya tanaman obat-obatan (bahan simplisia). Bengkulu.

Prayitno H (2015) 'Uji aktivitas antifungal ekstrak metanol mentah rimpang jeringau merah (acorus calamus linn.) terhadap pertumbuhan malassezia furfur secara in vitro', Mahasiswa PSPD FK Universitas Tanjungpura, 3(1), p. 3.

Puspadewi, R., Adirestuti, P. and Menawati, R. (2013) 'Khasiat umbi bawang dayak (eleutherine palmifolia (1.) merr.) sebagai herbal antimikroba kulit', Kartika Jurnal Ilmiah Farmasi, 1(1), p. 2.

Rojas, F. D. et al. (2017) 'Antifungal susceptibility testing of Malassezia yeast: comparison of two different methodologies', Mycoses, 60(2), pp. 104-111.

Ronaa, H. et al. (2018) 'Comparison of effectiveness between celery juice (apium graveolens 1.) and $2 \%$ miconazole towards the growth of malassezia furfur', Proceedings of the International Conference on Applied Science and Health, (3), pp. 73-77.

Sarbadhikary, S. B. et al. (2015) 'Original Research Article Antimicrobial and Antioxidant Activity of leaf extracts of two indigenous angiosperm species of tripura', International Journal Of Current Microbiology And Applied Sciences, 4(8), pp. 643-655.

Schoffelmeer, E. A. M. et al. (1999) 'The cell wall of fusarium oxysporum', Fungal Genetics and Biology, 27(2-3), pp. 275-282. doi: 10.1006/fgbi.1999.1153.

Scorzoni, L. et al. (2017) 'Antifungal therapy: new advances in the understanding and treatment of mycosis', Frontiers in Microbiology, 8(1), pp. 1-23.

Shibata, N. et al. (2009) 'The cell wall galactomannan antigen from malassezia furfur and malassezia pachydermatis 
contains $\quad \beta$-1,6-linked linear galactofuranosyl residues and its detection has diagnostic potential', Microbiology, 155(10), pp. 3420-3429. doi: 10.1099/mic.0.029967-0.

Shukla, N. and Bhalodia, R. (2011) 'Antibacterial and antifungal activities from leaf extracts of cassia fistula 1.: an ethnomedicinal plant', J Adv Pharm Technol Res, 2(2), pp. 104-9.

Singh, M., Jha, A. and Kumar, A. (2014) 'Influence of the solvents on the extraction of major phenolic compounds ( punicalagin, ellagic acid and gallic acid ) and their antioxidant activities in pomegranate aril', J Food Sci Technol, 51(9), pp. 2070-2077. doi: 10.1007/s13197-014-1267-0.

Stalhberger, T. et al. (2014) 'Chemical organization of the cell wall polysaccharide core of malassezia restricta', Journal of Biological Chemistry, 289(18), pp. 12647-12656. doi: 10.1074/jbc.M113.547034.

Sulistyawati, L. R., Natalia, D. and Mahyarudin, M. (2018) 'Uji aktivitas antijamur ekstrak etanol eleutherine americana. merr. terhadap trichophyton tonsurans secara in vitro', Majalah Kedokteran Andalas, 41(1), pp. 22-31.

Sutton, S. (2011) 'Determination of inoculum for microbiological testing', Journal of GXP Compliance, 15(3), pp. 49-53. doi: 10.1002/9780470054581.

Uehling, J., Deveau, A. and Paoletti, M. (2017) 'Do fungi have an innate immune response? an nlr-based comparison to plant and animal immune systems', PLoS Pathogens, 13(10), pp. 1-8. doi: 10.1371/journal.ppat.1006578.

Vandeputte, P., Ferrari, S. and Coste, A. T. (2012) 'Antifungal resistance and new strategies to control fungal infections', International Journal of Microbiology, 2012. doi: $10.1155 / 2012 / 713687$.

Vijayakumar, R. et al. (2006) 'Characterization of malassezia furfur and its control by using plant extracts', Indian J Dermatol, 51, pp. 145-8.

Wahyuni, R., Guswandi, G. and Rivai, H. (2014) 'Pengaruh cara pengeringan dengan oven, kering angin dan cahaya matahari langsung terhadap mutu simplisia herba sambiloto', Jurnal Farmasi Higea, 6(2), p. 129.

Yanti, A. R., Mudahar, H. and Irawan, I. (2008) 'DARI EKSTRAK ETIL ASETAT KULIT BATANG SULATRI ( Calophyllum soulattry Burn .f .)', pp. 158-161.

Yurayart, C. et al. (2013) 'Antifungal agent susceptibilities and interpretation of malassezia pachydermatis and Candida parapsilosis isolated from dogs with and without seborrheic', Med Mycol, 51(7), pp. 721-730. 